\title{
New perspectives on the role of customer satisfaction and commitment in promoting customer citizenship behaviours
}

\begin{tabular}{|c|c|}
\hline \multicolumn{2}{|c|}{$\begin{array}{l}\text { Authors: } \\
\text { Estelle van } \text { Tonder }^{1} \text { (]) } \\
\text { Leon T. de Beer }{ }^{2}\end{array}$} \\
\hline \multicolumn{2}{|c|}{$\begin{array}{l}\text { Affiliations: } \\
{ }^{1} \text { School of Management } \\
\text { Sciences, Faculty of Economic } \\
\text { and Management Sciences, } \\
\text { North-West University, } \\
\text { South Africa }\end{array}$} \\
\hline \multicolumn{2}{|c|}{$\begin{array}{l}{ }^{2} \text { WorkWell Research Unit, } \\
\text { North-West University, } \\
\text { South Africa }\end{array}$} \\
\hline \multicolumn{2}{|c|}{$\begin{array}{l}\text { Corresponding author: } \\
\text { Estelle van Tonder, } \\
\text { 25621610@nwu.ac.za }\end{array}$} \\
\hline \multicolumn{2}{|c|}{$\begin{array}{l}\text { Dates: } \\
\text { Received: } 11 \text { Apr. } 2017 \\
\text { Accepted: } 28 \text { Sept. } 2017 \\
\text { Published: } 28 \text { Mar. } 2018\end{array}$} \\
\hline \multicolumn{2}{|c|}{$\begin{array}{l}\text { How to cite this article: } \\
\text { Van Tonder, E. \& De Beer, L.T., } \\
2018 \text {, 'New perspectives on } \\
\text { the role of customer } \\
\text { satisfaction and commitment } \\
\text { in promoting customer } \\
\text { citizenship behaviours', South } \\
\text { African Journal of Economic } \\
\text { and Management Sciences } \\
21(1), \text { a1894. https://doi. } \\
\text { org/10.4102/sajems. } \\
\text { v21i1.1894 }\end{array}$} \\
\hline \multicolumn{2}{|c|}{$\begin{array}{l}\text { Copyright: } \\
\text { (c) 2018. The Authors. } \\
\text { Licensee: AOSIS. This work } \\
\text { is licensed under the } \\
\text { Creative Commons } \\
\text { Attribution License. }\end{array}$} \\
\hline \multicolumn{2}{|l|}{ Read online: } \\
\hline 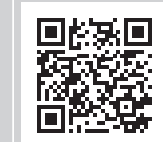 & $\begin{array}{l}\text { Scan this QR } \\
\text { code with your } \\
\text { smart phone or } \\
\text { mobile device } \\
\text { to read online. }\end{array}$ \\
\hline
\end{tabular}

Background: It is widely accepted that the relationship quality dimensions of customer satisfaction and commitment may impact on customer citizenship behaviour. The positive effect of customer satisfaction on customer commitment is also undisputed within the relationship marketing literature.

Aim: It was the aim of this study to examine the extent to which customer commitment mediates and strengthens the relationship between customers' perceived satisfaction and their citizenship behaviour. In the context of Internet banking, the study aimed to examine the extent to which customer's commitment towards the service provider (the bank) strengthens the relationship between satisfaction with the service provided (Internet banking) and customer citizenship behaviour (consumer advocacy and the helping of other customers).

Setting: The study was conducted in the South African Internet banking environment, which could benefit from a model of factors contributing to customer citizenship behaviour, specifically the sub-dimensions of consumer advocacy and helping behaviour.

Methods: A descriptive and quantitative research design was followed and the survey responses obtained from 491 existing users of Internet banking services were used in the analysis.

Results: Following the structural equation model results, the direct relationships between all constructs were confirmed. Customer commitment, however, has only a partial mediating effect on the relationships between customer satisfaction and the sub-dimensions of consumer advocacy and helping behaviour.

Conclusions: From a theoretical perspective, the research findings provide more insight into the role of customer satisfaction and commitment in contributing to customer citizenship behaviour and the extent to which both relationship quality factors are needed in order to do so. From a practical perspective, banks should adapt their marketing strategies to facilitate greater relationships with customers responsible for citizenship behaviours. Customers promoting the benefits of the service to other customers and helping them to use the service may ultimately contribute to greater adoption and use of Internet banking services.

\section{Introduction}

The notion that customers act as 'partial employees' of a firm and through their discretionary voluntary behaviours contribute to its competitive position is receiving growing attention in marketing literature (Balaji 2014; Chiu, Kwag \& Bae 2015:627; Fowler 2014; Jung \& Yoo 2016; Tung, Chen \& Schuckert 2017; Wu et al. 2017). This behaviour is generally referred to as customer citizenship behaviour and has been formally defined as 'helpful constructive gestures exhibited by customers that are valued or appreciated by the firm, but not related directly to enforceable or explicit requirements of the individual's role' (Gruen 1995:461). Hence, in addition to the in-role behaviours normally expected of customers (Patterson, Razzaque \& Terry 2003), such as paying for the service delivered, customers may perform extra-role behaviours that are not expected of them, for instance, having conversations with employees of the firm to provide feedback to them or recommending the service to other customers (Yi \& Gong 2008:969). Customers, however, do not receive remuneration for these citizenship actions that ultimately may enhance the firm's service experience.

It further appears that relationship quality may impact on customer citizenship behaviour. Specifically, the relationship quality dimensions of customer satisfaction and 
commitment (Vesel \& Zabkar 2010:1336) have often been examined as antecedents of customer citizenship behaviour (Chiu et al. 2015; Curth, Uhrich \& Benkenstein 2014; Paillé, Grima \& Dufour 2015; Patterson et al. 2003; Ponnusamy \& Ho 2015). The predictive effect of these two factors on the citizenship behaviour of customers is explained by social exchange theory (Blau 1964). It is believed that customers who are satisfied with the service received and who have become attached to the firm may want to reciprocate and give back to the firm by displaying customer citizenship behaviour (Anaza \& Zhao 2013:133; Yi \& Gong 2008:967). A further interesting observation, however, is that within the relationship marketing domain, customer commitment is also viewed as an outcome of customer satisfaction (Hennig-Thurau 2004:465) and is perceived as fundamental in all relational exchanges (Morgan \& Hunt 1994:23). Hence, considering previously established relationships between commitment and the variables customer satisfaction and customer citizenship behaviour, it is plausible that customer commitment could also serve as a mediating variable to strengthen the relationship between customers' perceived satisfaction and their citizenship behaviours. However, greater clarity is required on this matter, which has been overlooked in academic research and that could ultimately make a valuable contribution to marketing theory and practice.

Specifically, from a theoretical perspective, the investigation may provide insight not only on the role of customer satisfaction and commitment in contributing to customer citizenship behaviour but also on the extent to which both relationship quality factors are needed in fostering such behaviour. From a practical perspective, an understanding of the relationships between customer satisfaction, commitment and customer citizenship behaviour may be particularly beneficial to the Internet banking environment. It appears that despite the growth in the digital industry, there are still sceptical consumers believing that in-branch banking services are safer and that electronic banking platforms must be avoided (News24 2015). Customer citizenship behaviour in the form of consumer advocacy and helping behaviour specifically (Yi \& Gong 2013) may present a solution to this problem. Existing users of Internet banking services, through advocating the benefits to other potential users and helping them to use the service correctly, may foster the greater adoption and use of these services. Managing these assisting behaviours successfully, however, requires knowing how customer satisfaction and commitment contribute to the advocacy and helping sub-dimensions of customer citizenship behaviour; this would enable the banks to manage their consumer value-adding strategies more appropriately.

Accordingly, to contribute further to research on relationship quality and customer citizenship behaviour, this study aimed to address the stated research gap and examine the extent to which customer commitment may act as a mediating variable in the relationship between customer satisfaction and customer citizenship behaviour. Specifically, the study was interested in exploring whether customers' commitment towards the service provider (the bank) would strengthen the relationship between satisfaction with the service provided (Internet banking) and customer citizenship behaviour (consumer advocacy and the helping of other customers).

The remaining sections of this article present the findings of this study. Firstly, an overview is provided of the South African banking industry, the research constructs of this study and the relationships proposed in the conceptual model. Next, the research methodology is outlined, followed by a discussion of the research findings and their theoretical and managerial implications. In the final part of the article, study limitations are noted and directions for further research are provided.

\section{Theoretical framework Overview of the South African banking industry}

The South African banking industry is strictly regulated by the South African Reserve Bank and has a well-developed banking system. There are five major role players in the field, namely ABSA, Standard Bank, Nedbank, FirstRand and Capitec Bank, which in the midst of economic challenges in the macroeconomic environment are delivering good financial results. Taking into account the number of customers per bank, FirstRand has the largest market share (11.1 million), followed by Standard Bank (9.2 million), ABSA (7.3 million), Nedbank (7.1 million) and Capitec Bank (6.2 million) (Petzer, De Meyer-Heydenrych \& Svensson 2017:243-244). Furthermore, while each major bank focuses on its own unique strategies best suited to its areas of strength, collectively the banks appear to have certain overlapping goals. Common objectives include diversification and enhancement of earnings profile across Africa, growth of transactional banking franchises and enhancements in electronic platform capabilities. Considering the digital objective in particular, the banks seem to be aware of important developments in the financial technology (fintech) environment and the need to focus on strategic partnerships to deliver the digital service. Great investments are being made in the banks' information technology systems to meet customer needs for smooth transactional banking and digital solutions. Overall, however, the fintech industry has not yet reached its full potential. Constraints hindering progress include long development cycles, legacy issues and the composition of the organisation (PwC 2016:7, 23). Another problem that appears to hinder the growth and adoption of digital platforms within the banking industry is perceptions of sceptical consumers that in-branch banking services are safer and that electronic banking platforms must be avoided. This problem seems to be important in the South African banking context as almost half (43\%) of all South Africans are still of the opinion that traditional over-the-counter transactions are safer than conducting business over the Internet (News24 2015). The citizenship behaviour performed by existing users of Internet banking services may present a solution to this problem. As positioned in the introduction to this article, customer citizenship behaviour involving 
customers advocating the benefits of the service to other customers and helping them to use the service safely and correctly may be of great assistance in convincing the sceptical portion of the bank's target market to convert to electronic banking services. The interrelationships among relationship quality factors contributing to these citizenship behaviours, however, have not been fully explored and require further investigation.

\section{Relationship marketing and relationship quality factors}

Relationship marketing has become a major school of thought in marketing literature over the years (Sheth 2017:4). One of the most widely accepted definitions is that of Berry (1983:25), who defines relationship marketing as 'attracting, maintaining, and - in multi-service organisations - enhancing customer relationships'. According to Sheth (2017:6), poor economic conditions in the early 1980s, which resulted in a period of stagnated economic growth and rising inflation (stagflation), served as a major driving force in the development of the relationship marketing domain, because it became more important to develop relationships with customers to generate business. The advancement of relationship marketing is also believed to be closely associated with the evolution of the service sector, which aims to build long-term relationships with customers. (Grönroos 1983; Gummerus, Von Koskull \& Kowalkowski 2017). The expectation is that service firms, to benefit over the long term, must focus on the core service and customise relationships according to the needs of the individual customer (Berry 1983). Therefore, to satisfy customers and to maintain them, firms must concentrate on relational exchanges instead of transactional exchanges (Gummerus et al. 2017). Ultimately, it is believed that the relationships established with customers will contribute to a sustainable competitive advantage (Jones et al. 2015:188). It is therefore imperative for firms to establish quality relationships with their customers. Relationship quality reflects the strength of the relationship between the firm and its customers (Garbarino \& Johnson 1999; Izogo 2017) and provides an indication of the closeness or intensity of the relationship (Hajli 2014:19; Vesel \& Zabkar 2010:1336). As mentioned in the introduction to this article, customer satisfaction and commitment are regarded as key indicators of relationship quality (Vesel \& Zabkar 2010:1336) and as such are further explored in this study.

\section{Customer satisfaction}

A number of key definitions have been formulated to explain the concept of customer satisfaction. For example, as cited by Kundu and Datta (2015:23) as well as Yuksel and Yuksel (2001:52), customer satisfaction has been described as 'the buyer's cognitive state of being adequately or inadequately rewarded in a buying situation for the sacrifice he has undergone' (Howard \& Sheth 1969), 'the consumer's evaluation of the extent to which the product or service fulfills the complete set of wants and needs' (Czepiel, Rosenberg \& Akerele 1974), 'the summary psychological state resulting when the emotion surrounding disconfirmed expectation is coupled with the consumer's prior feeling about the consumption experience' (Oliver 1981) and 'a person's feeling of the pleasure or disappointment arising from comparing products' perceived performance in relation to expectation'. From these descriptions, it seems that the central tenet of customer satisfaction is that it concerns expectations prior to purchasing and opinions formed about the performance after the purchase has been made (Kundu \& Datta 2015:23). This behaviour is commonly referred to as the expectancy-disconfirmation paradigm, professing that customers tend to relate the actual performance of a product or service to the set of expectations they held about the performance before the encounter. Customers will be satisfied if expectations are met or surpassed, and dissatisfied if the product or service has failed to meet their expectations (Caruana 2002:815; Narteh 2015:363; Pizam \& Ellis 1999:28; Yuksel \& Yuksel 2001:58). Perceptions pertaining to expectations and actual performance may further include both cognitive and affective responses (Narteh 2015:363; Oliver 1989:1; Spreng \& Mackoy 1996:202). The cognitive response refers to a psychological interpretation of the difference between the product or service expected and that received, whereas the affective response concerns a customer's feelings both during and after the consumption process (Narteh 2015:363).

Measuring customer satisfaction based on customer expectations and performance perceptions, though, is not a practice accepted by all researchers. Some scholars argue that the customer satisfaction concept is very similar to that of service quality (Yuksel \& Yuksel 2001:54), as the definitions for both allude to comparisons between customer expectations and the actual performance of a product offering (Iacobucci, Ostrom \& Grayson 1995:278). Oliver (1993) sheds more light on the matter by stating that, unlike service quality, nonquality issues may also have an impact on satisfaction judgements, that perceptions of satisfaction necessitate experience with the service provider and that a greater range of factors may contribute to customer satisfaction. This view is also supported by researchers who believe that perceived service quality is an attitude, whereas satisfaction is perceived to be related to a business transaction (Bitner 1990; Bolton \& Drew 1991; Cronin \& Taylor 1994; Parasuraman, Zeithaml \& Berry 1988; Yuksel \& Yuksel 2001:55).

For the purpose of this study, the view by Oliver (1993) was adopted and customer satisfaction was assessed considering both the cognitive and affective dimensions of the concept. Accordingly, customer satisfaction was regarded as customers' cognitive beliefs concerning the service expected and experienced as well as the feelings they associate with this event.

\section{Customer commitment}

The construct commitment was originally explored within the organisational science literature, and it concerns the level of commitment demonstrated by employees towards their firms (Allen \& Meyer 1990). Over time, the construct has also 
been adopted into the marketing literature (Shukla, Banerjee \& Singh 2016:324) and is considered an important dimension of the relationship marketing theory. Principally, commitment concerns a willingness between partners to forfeit short-term benefits in order to profit from the relationship over the long term (Anderson \& Weitz 1992; Shukla et al. 2016:324). Customer commitment then relates to a 'lasting or enduring intention to build and maintain an ongoing relationship [with the firm]' (Izogo 2017:22; Morgan \& Hunt 1994).

It is further believed that customer commitment comprises three sub-dimensions, namely affective, normative and calculative commitment, which provides more insight into the reasons why customers would want to remain committed to the firm. Affective commitment relates to the customer's emotional attachment to the firm and a feeling that the customer belongs with the firm. Normative commitment refers to the obligation a person may feel to continue the relationship with the firm and to customer perceptions that it would not be right to defect to another provider even if the opportunity was provided. Calculative commitment concerns a person's intention to remain in a relationship because the sacrifice of ending the relationship would be too great (Allen \& Meyer 1990; Jones et al. 2010:17; Shukla et al. 2016:328).

\section{The social exchange theory and customer citizenship behaviour dimensions}

The concept of customer citizenship behaviour is grounded in the social exchange theory. According to this theory, people participate in a series of interdependent interactions that lead to obligations among the exchange parties. People who have benefited to some extent by the actions of a party may feel obligated to return the favour (Blau 1964; Emerson 1976; Gilde et al. 2011:620; Homans 1958; Mitchell, Cropanzano \& Quisenberry 2012:99). Applying the theory to the service business environment may in effect mean that customers experiencing a positive encounter would, for example, want to return the favour, at no extra cost, by displaying customer citizenship behaviour. Thus far, Bove et al. (2009) have proposed the most comprehensive measure of customer citizenship behaviour in the services marketing context (Gilde et al. 2011:620). According to Bove, Robertson and Pervan (2003:332) and Bove et al. (2009), customer citizenship behaviour includes action such as positive word-of-mouth behaviour (favourable informal communication about aspects of the organisation), relationship affiliation (using tangible displays or personal items to communicate a relationship with the organisation), suggestions for service improvements (not related to specific instances of consumption), customer policing (ensuring appropriate behaviour), voicing behaviour (communicating service failure to the organisation for improvement), being flexible (willingness to adapt to situations), benevolent acts of service (charitable acts), facilitation and taking part in the activities of the organisation (such as research or other sponsored activities). Yi and Gong (2013:1279), in another comprehensive study of the subject, later developed and validated a customer co-creation scale and identified the following as important dimensions of customer citizenship: feedback to the firm, advocating the benefits of the service to other customers, helping other customers with the service and being tolerant with levels of service delivery. From the various dimensions identified, it is evident that customer citizenship behaviour relates to the positive extra-role behaviour customers display that will contribute to the organisation's being more successful (Gilde et al. 2011:620).

Examining all the dimensions of customer citizenship behaviour, however, falls beyond the scope of this study. Instead, it is the aim of this article to explore only the advocacy and helping behaviour dimensions of this concept. These two dimensions were selected because they may represent relevant forms of customer citizenship behaviour within an Internet banking environment and may assist in addressing the slow adoption problem experienced in the electronic banking industry (News24 2015). As mentioned earlier, customer citizenship behaviour involving customers advocating the benefits of the service to other customers and helping them to use the service safely and correctly may be of great assistance in convincing the sceptical portion of the bank's target market to convert to electronic banking services.

\section{Consumer advocacy behaviour}

Consumer advocacy is related to consumer helping behaviour but is still a construct in its own right (Chelminski \& Coulter 2011:362). Advocacy concerns having conversations with friends and family in which the service firm is endorsed and may include positive remarks about the firm, recommendation of its service and encouragement to use it (Balaji 2014:224; Yi \& Gong 2013:1280-1281). Usually, customers who are at ease in their relationships with the service firm can be expected to display advocacy behaviour (Fullerton 2003:335) and to promote the firm's interest. This voluntary behaviour displayed through positive word-of-mouth may result in a number of benefits for the firm, including a positive image and an expanded customer base (Yi \& Gong 2013:1280-1281).

\section{Helping behaviour}

Consumer helping behaviour is an area that to a large extent has been overlooked in marketing research (Bendapudi, Singh \& Bendapudi 1996). It appears that some consumers are of opinion that it is their responsibility to help other consumers (Chelminski \& Coulter 2011:362). There are also perceptions that people help one another for altruistic reasons or because it is rewarding in nature (Hibbert, Hogg \& Quinn 2002). Thus, some consumers enjoy being actively involved in assisting consumers and sharing their own shopping information with them. Consumers may help other consumers to allow them to have positive experiences in the consumer marketplace (Chelminski \& Coulter 2011:362). Generally, consumers may receive assistance from fellow consumers in finding products, fixing them, or using them properly (Johnson, Massiah \& Allan 2013:122). Consumer helping behaviour is not restricted to the non-durable and durable goods market, but may also be present within a services context (Price, Feick \& Guskey 1995:255). Firms 
benefit by these voluntary behaviours as customers' helping of others may contribute to business success (Johnson et al. 2013:122).

\section{Theoretical model}

The proposed theoretical model comprises several relationships, as detailed below.

\section{The link between customer satisfaction and commitment}

It is believed that customer satisfaction may lead to commitment. For example, Hennig-Thurau (2004:465) writes: 'A high level of satisfaction provides the customers with a repeated positive reinforcement, thus creating commitmentinducing emotional bonds'. Satisfaction relates to the fulfilment of social needs. The repeated occurrence of this behaviour may contribute to emotional bonds that could also result in commitment (Hennig-Thurau, Gwinner \& Gremler 2002:237; Hennig-Thurau \& Klee 1997). Empirical evidence of the relationships between customer satisfaction and commitment have been found in studies relating to the luxury motor vehicle environment (Van Tonder, Petzer \& Van Zyl 2017); the retailing, entertainment, banking and transportation services environment (Dimitriades 2006); and the entertainment environment involving customers of an Off Broadway theatre company (Johnson, Sivadas \& Garbarino 2008).

In the present study the research context is the Internet banking environment, and it examines the extent to which customers are satisfied with the Internet banking service provided. Considering the previously established relationships between the satisfaction and commitment constructs, it is argued in this study that customers' satisfaction with their Internet banking services may affect their levels of commitment towards the bank (the service provider). Customers who are satisfied with the service received from the bank may want to continue their business relationship with it. The plausibility of this relationship is further emphasised by the work of Gruca and Rego (2005:115), noting that customer satisfaction may elicit desirable behaviours, such as consumers being more inclined to engage in cross-selling opportunities from the same provider. Satisfied customers who purchase more products from the same provider will remain committed to the firm and continue their relationship with it. The first hypothesis of this study consequently states that:

$\mathbf{H}_{1}$ : Customer satisfaction with Internet banking services has a positive and significant effect on customer commitment towards the bank.

\section{Customer satisfaction and commitment as antecedents of customer citizenship behaviour}

Several scholars are of the opinion that customer satisfaction may impact customer citizenship behaviour (Anaza \& Zhao 2013:133; Chen, Chen \& Farn 2010; Groth 2005:13). The link between customer satisfaction and the resulting citizenship behaviour can be explained by the social exchange theory.
Customers who are satisfied with the firm tend to believe that the firm has fulfilled its contractual obligation of providing excellent service. Accordingly, customers may want to reciprocate the favour by engaging in voluntary citizenship behaviour (Anaza \& Zhao 2013:133; Yi \& Gong 2008:966-967). Positive relationships between customer satisfaction and customer citizenship behaviour, involving customer recommendations and helping behaviour, have also been noted in academic literature (Anaza 2014:255; Anaza \& Zhao 2013:133).

Furthermore, the potential impact of commitment on the voluntary behaviours of consumers, including advocacy and helping behaviour, has also previously been documented (Jones et al. 2010:16, 17, 22). It appears that all three dimensions of customer commitment may have an impact on customer citizenship behaviour. Specifically, the effect of affective commitment on customer citizenship behaviour can be explained by the emotional attachment felt by highly committed consumers towards a firm, and the extent to which they identify with the firm's objectives and values. Customers having these feelings of emotional attachment and identification tend to be concerned about the firm's well-being and would be willing to reciprocate its efforts by displaying customer citizenship behaviour (Yi \& Gong 2008:967). Additionally, it has been stated that normatively committed customers may have a felt obligation to display discretionary behaviours. A positive relationship between customers displaying calculative or continuance commitment and making voluntary discretionary investments has also been empirically confirmed (Jones et al. 2010:18, 22).

Accordingly, it is further hypothesised in this study that:

$\mathbf{H}_{2}$ : Customer satisfaction with Internet banking services has a positive and significant effect on advocacy behaviour.

$\mathbf{H}_{3}$ : Customer satisfaction with Internet banking services has a positive and significant effect on helping behaviour.

$\mathbf{H}_{4}$ : Customer commitment towards the bank has a positive and significant effect on advocacy behaviour.

$\mathbf{H}_{5}$ : Customer commitment towards the bank has a positive and significant effect on helping behaviour.

Considering the proposed relationships noted in the first four hypotheses, two additional hypotheses were formulated to assess the potential mediating effect of customer commitment on the relationships between customer satisfaction and the customer citizenship dimensions of consumer advocacy and helping behaviour:

$\mathbf{H}_{6}$ : Customer commitment towards the bank mediates the relationship between customer satisfaction with Internet banking services and advocacy behaviour.

$\mathbf{H}_{7}$ : Customer commitment towards the bank mediates the relationship between customer satisfaction with Internet banking services and helping behaviour.

Figure 1 provides a summary of the research hypotheses that were formulated in this section. 


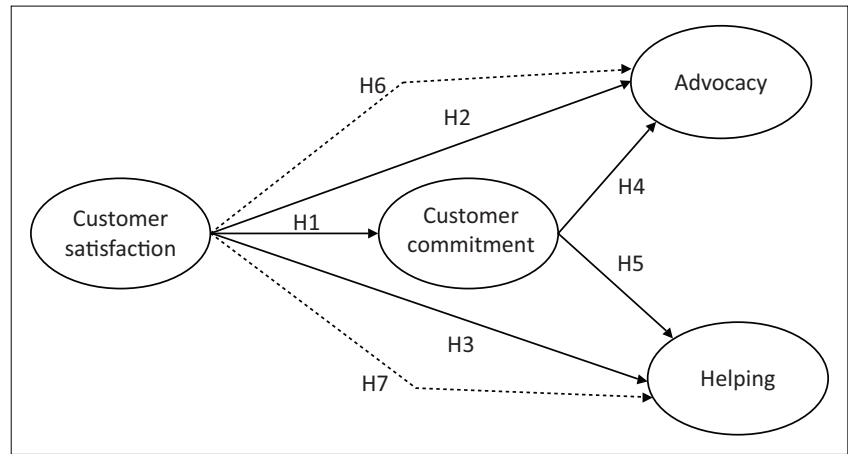

FIGURE 1: Conceptual model.

\section{Research methodology Design, target population and sample}

The conceptual model was empirically tested with data from a cross-sectional survey. The research design was quantitative and descriptive in nature, and the target population was respondents in South Africa who use Internet banking services. As a comprehensive list of the target population was not available, a non-probability convenience sampling method was used to select the respondents for the study. [According to the Protection of Personal Information Act 4 of 2013, retail banks in South Africa are not permitted to disclose any information regarding their clients (South Africa 2013)]. A total of 250 male and 250 female respondents were targeted to fill gender quotas and ensure that feedback obtained would be equally representative of both genders. Male and female respondents forming part of the target population were approached by a fieldworker in public places and were invited to participate in the study. If the respondent refused, the next available respondent forming part of the target population was approached.

\section{Questionnaire}

A self-administered questionnaire was designed that included a screening question to ensure that only respondents making use of Internet banking services would be permitted to take part in the study. The first section of the questionnaire obtained more detail on the demographic profiles of the respondents. The subsequent sections focused on respondent perceptions pertaining to customer satisfaction with Internet banking services, customer commitment towards the bank and the extent to which the respondents had engaged in advocacy and helping behaviour towards other consumers. Measurement items from well-established scales that had previously proved to be valid and reliable were selected for the purpose of this study. The measurement items chosen were representative of the core facets of each construct, as discussed in the literature review. The concept of customer satisfaction was measured using the scale of Dagger and O'Brien (2010:1551), with six measurement items, and included both cognitive and affective responses. Advocacy and helping behaviour were measured using the scales provided by Yi and Gong (2013:1281), with three and four measurement items, respectively. Customer commitment towards the banking institution was assessed using the scale of Smith (1998:92), with four measurement items, and it assessed commitment from an overall perspective. All scales were adapted to ensure alignment to the context of this study. Table 2 provides a summary of the measurement items that were included in the survey. The respondents were requested to rate each statement on a 5-point Likert-type scale. The scores ranged from 1 signifying 'strongly disagree' to 5, representing 'strongly agree'. Prior to completing the survey, the respondents were ensured that taking part in the study was completely voluntary and anonymous and that their responses would be kept confidential.

\section{Data analysis}

The edited and cleaned data were entered into the SPSS 24.0 statistical package, and frequency statistics, descriptive statistics and Cronbach's alphas were calculated to determine the demographic profile of the respondents and the mean values of each construct and to assess construct reliability. Mplus 7.4 was used to conduct a confirmatory factor analysis (CFA) of the measurement model with the maximum likelihood estimation procedure. The CFA was applied within the structural equation model (SEM) framework (Brown 2015). Model fit was assessed by studying the Comparative Fit Index (CFI; acceptable values between 0.90 and 0.99), the TuckerLewis Index (TLI; acceptable values between 0.90 and 0.99), the root mean square error of approximation (RMSEA; acceptable values of < 0.08) (Van de Schoot, Lugtig \& Hox 2012), and the standardised root mean residual (SRMR; acceptable values of < 0.05) (Byrne 1998). The guidelines of Cohen (1992) were used to determine the cut-off points for correlation coefficients. Correlations between 0.30 and 0.49 therefore were considered to have a medium practical effect, and correlations equal to and greater than 0.50 were perceived to have a large practical effect. Validity was assessed using the results obtained from the CFA analysis. Structural regression paths were then added to the measurement model (CFA), in accordance with the research hypotheses formulated (Muthén \& Muthén 2016) and to ascertain the various relationships within the structural model. Moreover, bootstrapping was also implemented to determine the potential indirect relationships (mediation) with 5000 draws from the data, and considering the $95 \%$ confidence intervals (CIs) of the estimates (Preacher \& Hayes 2008). Statistical significance for all model parameters assessing the indirect effects was set at the 95\% level $(p<0.05)$.

\section{Ethical consideration}

A low risk study was conducted that complied with the ethical guidelines of North-West University.

\section{Results and findings Demographic profile}

In the end a total of 491 surveys were obtained from the field and were deemed adequate for further statistical analysis, resulting in a response rate of $98 \%$. Although the researchers endeavoured to obtain feedback from an equal number of male and female respondents, $53.4 \%$ male and $46.6 \%$ female 
respondents participated in the study. All the respondents were making use of Internet banking. Respondents from various racial groups completed the survey: most of them were white respondents $(57.5 \%)$, followed by black respondents $(18.8 \%)$, mixed race respondents $(13.7 \%)$, Indian respondents $(5.7 \%)$ and Asian respondents (4.3\%). The respondents were further requested to select the bank where most of their personal banking transactions are normally conducted. ABSA was selected most often (27.3\%), followed by FirstRand (20.8\%), Capitec Bank (20.4\%), Standard Bank $(14.3 \%)$, Nedbank (13.2\%) and other banks (4.1\%). Although these findings do not correspond with the market share of the five major South African banks, as discussed in the literature review, the statistics still provide evidence that the current data set reflects the perceptions of customers from all five major banks.

\section{Measurement model}

Sampling adequacy was first assessed. It was determined that the overall Kaiser-Meyer-Olkin test statistic is greater than the general cut-off value of 0.6 (0.873), and Bartlett's test of sphericity presented significant results $(p<0.05)$. Hence, the data were considered suitable for further analysis. The subsequent CFA, with all of the latent variables specified and with all of the respective corresponding items, provided the following model fit output: CFI (0.93), TLI (0.91), RMSEA (0.10) and SRMR (0.05). Upon inspection of the factor loadings, it was shown that the first and last items of customer satisfaction had loadings below 0.70 (Hair et al. 2010) and were removed from the model. The respecified CFA executed successfully and provided superior fit indices: CFI (0.96), TLI (0.95), RMSEA (0.07) and SRMR (0.04). Additionally, the chi-square (365.704)/degrees of freedom (84) ratio was less than 5 (4.35). Hence, it was considered acceptable to continue interpreting the correlations of these latent variables.

Table 1 presents the correlation matrix for the latent variables generated from the CFA, as well as the corresponding average variance extracted (AVE) values and mean values obtained for each construct.

From Table 1, it is evident that customer satisfaction had a positive relationship with customer commitment $(r=0.27$; small effect), bordering a medium effect size. Customer satisfaction also had positive relationships with advocacy $(r=0.61$; large effect) and helping $(r=0.48$; medium effect $)$. Furthermore, customer commitment had a positive relationship with advocacy ( $r=0.38$; medium effect) and helping ( $r=0.24$; small effect). Helping and advocacy also had a positive relationship $(r=0.58$; large effect $)$. Supportive evidence was also found for discriminant validity between the constructs, as all of the AVE values were above the squared correlation coefficients between the variables (Fornell \& Larcker 1981; Hair et al. 2010). For example, the squared correlation for the relationship between customer satisfaction and advocacy was 0.37 , but the AVE values in customer satisfaction (0.72) and advocacy (0.75) were well above that value, indicating that more variance is explained in the constructs than shared variance between them.

Furthermore, the mean scores for the constructs were relatively positive: customer satisfaction $(\mathrm{M}=4.10$; $\mathrm{SD}=$ $0.57)$, customer commitment $(\mathrm{M}=3.61 ; \mathrm{SD}=0.73)$, advocacy $(\mathrm{M}=3.84 ; \mathrm{SD}=0.73)$ and helping $(\mathrm{M}=3.74 ; \mathrm{SD}=0.75)$. This indicates that participants were more likely to lean towards the positive end of the 5-point scale, which was scored from 'strongly disagree' to 'strongly agree'.

Table 2 provides more insight into the standardised factor loadings of the individual measurement items as well as the construct reliabilities and Cronbach's alpha values that were obtained for each construct.

As shown in Table 2, all factors loaded significantly onto their individual constructs $(p<0.001)$. The lowest loading was for item one of advocacy ('I have said positive things about this Internet banking service I use to other people, such as my friends, relatives or co-workers') but close to the ideal 0.70 cut-off value as suggested by Hair et al. (2010) and adopted in this study. All AVE values also exceeded 0.5 (Table 1), and the composite reliability value for each latent variable is greater than the cut-off value of 0.7 (Table 2). Therefore, from these findings it can be concluded that the latent variables of customer satisfaction, commitment, advocacy and helping behaviour show reliability and convergent validity. Additionally, Table 2 indicates that the Cronbach's alpha values for each factor are above the cutoff value of 0.7 (DeVellis 2012; Tabachnick \& Fidell 2001), providing further evidence of internal consistency of the research constructs.

\section{Structural model analysis}

The results of the structural model are presented in Table 3.

TABLE 1: Correlation matrix for the latent variables with average variance extracted on the diagonal and mean values.

\begin{tabular}{llll}
\hline Variables & $\mathbf{1}$ & $\mathbf{2}$ & $\mathbf{3}$ \\
\hline 1. Customer satisfaction & $(0.72)$ & - & - \\
2. Customer commitment & $0.27^{\mathrm{a}}$ & $(0.76)$ & - \\
3. Advocacy & $0.61^{\mathrm{b}}$ & $0.38^{\mathrm{a}}$ & - \\
4. Helping & $0.48^{\mathrm{c}}$ & $0.24^{\mathrm{a}}$ & $(0.75)$ \\
\hline
\end{tabular}

Note: All correlations statistically significant at $p<0.001$. AVE on the diagonal in brackets; AVE, average variance extracted.

a, Small effect; ${ }^{\text {b }, ~ L a r g e ~ e f f e c t ; ~ c, ~ M e d i u m ~ e f f e c t . ~}$

AVE, average variance extracted. 
TABLE 2: Measurement model: standardised factor loadings, construct reliability and Cronbach's alpha values.

\section{Construct, item}

\section{Customer satisfaction} Standardised factor loadings

I am always delighted with the Internet banking service provided by my bank.

Overall I am satisfied with the Internet banking service provided by my bank.

$\begin{array}{lll} & 0.91 & 0.89 \\ 0.86 & - & - \\ 0.90 & - & - \\ 0.85 & - & - \\ 0.76 & - & - \\ & 0.93 & 0.93\end{array}$

I feel good about using the Internet banking service provided by my bank.

Customer commitment

I believe my bank and I are both committed to the relationship.

I have a strong sense of loyalty towards my bank.

My bank is prepared to make short-term sacrifices to maintain our relationship.

I believe my bank and I view our relationship as a long-term partnership.

\section{Advocacy}

0.90

0.93

0.83

0.82

I have said positive things about this Internet banking service I use to other people, such as my friends, relatives or co-workers.

I have recommended the Internet banking service I use to other people, such as my friends, relatives or 0.95 co-workers.

I have encouraged other people such as friends, relatives or co-workers to use the Internet banking service. 0.96

\section{Helping}

Previously, I have assisted other people such as friends, relatives or co-workers who needed help using Internet banking.

I have helped other people such as friends, relatives or co-workers in the past if they seemed to have problems using Internet banking.

I have taught other people such as friends, relatives or co-workers to use the Internet banking service correctly.

I have given advice to other people such as friends, relatives or co-workers in the past regarding Internet banking services.

Note: All factors loaded significantly at $p<0.001$.

TABLE 3: Regression results for the structural model.

\begin{tabular}{llll}
\hline Structural path & Standardised $\boldsymbol{B}$ & SE & Result \\
\hline $\begin{array}{l}\text { H1: Customer satisfaction } \rightarrow \text { Customer } \\
\text { commitment }\end{array}$ & 0.27 & 0.05 & $0.001^{*}$ \\
H2: Customer satisfaction $\rightarrow$ Advocacy & 0.54 & 0.04 & $0.001^{*}$ \\
H3: Customer satisfaction $\rightarrow$ Helping & 0.45 & 0.05 & $0.001^{*}$ \\
H4: Customer commitment $\rightarrow$ Advocacy & 0.24 & 0.04 & $0.001^{*}$ \\
H5: Customer commitment $\rightarrow$ Helping & 0.12 & 0.05 & $0.007^{*}$ \\
\hline
\end{tabular}

B, beta coefficient; $\mathrm{SE}$, standard error; $\mathrm{H}$, hypothesis.

*, Two-tailed statistical significance at $p<0.001 ; * *$, Two-tailed statistical significance at $p<0.01$.

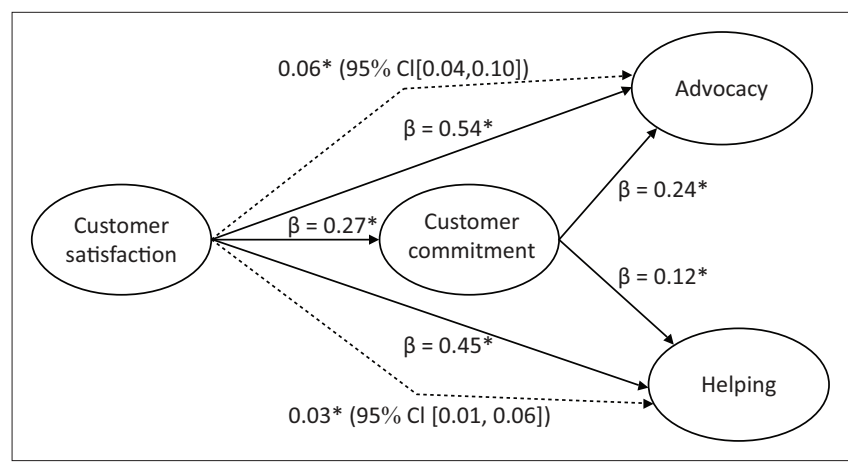

FIGURE 2: Structural model.

As can be seen from Table 3, all the regressions were significant and positive. Specifically, customer satisfaction had a significant regression to customer commitment $(\beta=$ $0.27 ; \mathrm{SE}=0.05 ; p<0.001 ; \mathrm{H} 1$ supported $)$, advocacy $(\beta=0.54 ;$ $\mathrm{SE}=0.04 ; p<0.001 ; \mathrm{H} 2$ supported $)$ and helping $(\beta=0.45$; $\mathrm{SE}=0.05 ; p<0.001 ; \mathrm{H} 3$ supported). Customer commitment in turn had significant regressions to both advocacy $(\beta=0.24$; $\mathrm{SE}=0.04 ; p<0.001 ; \mathrm{H} 4$ supported $)$ and helping $(\beta=0.12$; $\mathrm{SE}=0.05 ; p=0.007 ; \mathrm{H} 5$ supported).
Lastly, the bootstrapping of the indirect effects revealed that customer satisfaction had an indirect relationship with advocacy [0.06; $p<0.001 ; 95 \%$ CI $(0.04,0.10)]$ and helping [0.03; p $=0.02 ; 95 \%$ CI $(0.01,0.06)]$ through customer commitment. Therefore, supportive evidence was found for customer commitment as a complementary (partial) mediator in these two relationships - as the direct relationships were also significant (Zhao, Lynch \& Chen 2010:201). Research hypotheses H6 and H7 were therefore supported.

Figure 2 provides a summary of the structural model results.

\section{Research implications, limitations and directions for further research Theoretical implications}

Several theoretical implications could be derived from this study's findings.

Firstly, considering the acceptance of the first research hypothesis, the findings of this study offer further 
confirmation of the impact of customer satisfaction on customer commitment (Hennig-Thurau 2004:465). The research findings of the current study, however, shed more light on the matter by indicating that customer satisfaction with the service received may contribute towards commitment towards the service provider. Marketing scholars generally tend to measure customer satisfaction and commitment within an online context by making reference only to the website used (see, for example Hamadi 2011). The findings from this study offer evidence that satisfaction with an online service received may also lead to commitment towards the firm providing the service.

Secondly, support is found of the relationship between customer satisfaction and customer citizenship behaviour and that between customer commitment and customer citizenship behaviour, as has been pointed out by previous scholars (Anaza \& Zhao 2013:133; Chen et al. 2010; Chiu et al. 2015; Curth et al. 2014; Groth 2005:13; Jones et al. 2010:16, 17, 22; Paillé et al. 2015; Patterson et al. 2003; Ponnusamy \& Ho 2015; Yi \& Gong 2008:967). The importance of relationship quality in impacting on customer citizenship behaviour is further verified by this study. Additionally, the acceptance of research hypotheses two to five indicates the effect of customer satisfaction and commitment on the advocacy and helping sub-dimensions of customer citizenship behaviour. The combination of these relationships has not been extensively investigated before. One article was found that confirmed these relationships within the context of fitness centres (Chiu et al. 2015), and the findings of the current study offer further confirmation.

Thirdly, while the potential impact of various forms of customer commitment on customer citizenship behaviour has been noted in the hypotheses section of this article, previous studies have concentrated largely on the direct effect between affective commitment and customer citizenship behaviour (Curth et al. 2014; Liu \& Mattila 2015). In the context of this study, customer commitment was measured from an overall perspective and consequently provides more insight into the matter. The established overall connection between customer commitment and the customer citizenship behaviour dimensions of this study offers evidence that the extra-role voluntary behaviour of customers may not depend solely on their degree of emotional attachment to the firm. Other dimensions of commitment may also be important and should be included in the investigation.

Finally, the acceptance of research hypotheses six and seven provides confirmation of the mediating effect of customer commitment on the relationship between customer satisfaction and the customer citizenship behaviour dimensions of advocacy and helping behaviour. It is interesting, however, that only a partial mediating effect could be found and that while the indirect effect is significant, it is relatively small compared to the direct effects of customer satisfaction with helping and advocacy behaviour. Hence, it appears that while both customer satisfaction and commitment may be required in fostering customer citizenship behaviour, the mediating effect of customer commitment is not very important in the model. Instead, it seems more essential to focus on the direct relationships of customer satisfaction and customer commitment with customer citizenship behaviour.

\section{Managerial implications}

From a practical perspective, the measurement model indicates that banks should focus on both customer satisfaction and commitment in facilitating customer citizenship advocacy and helping behaviour. The direct effect of customer satisfaction with customer citizenship behaviour, however, is greater than the direct effect of customer commitment and customer citizenship. Hence, it may be more important for banks to ensure that their customers are satisfied with the online service provided than to engage in strategies to gain customer commitment. To foster customer satisfaction with online services, banks could, for example, take measures to ensure that their systems are operational at all times, the Internet banking interface is easy to use and aligned to customer needs, and assistance is available to address customer queries promptly. These behaviours may lead to customer citizenship behaviour and could assist in making customers more committed towards the bank. Considering that customer satisfaction and commitment are key dimensions of relationship quality, the findings of the measurement model highlight the importance of relationship marketing practices in the Internet banking environment and support the view that relationship marketing practices are still relevant in the modern marketing milieu (Brodie 2017; Gummerus et al. 2017; Gummesson 2017; Payne \& Frow 2017; Sheth 2017). Finally, banks should acknowledge that the established customer citizenship behaviours in this study offer confirmation that customers are taking over the traditional marketing role and becoming responsible for promoting the service and teaching other customers to use the service. The role of the marketer is consequently changing, and marketing strategies should be formulated accordingly to facilitate greater relationships with customers responsible for citizenship behaviour.

\section{Limitations and directions for further research}

This study has some limitations that could be addressed in further studies. The study had to rely on a non-probability sampling approach and provided valuable insight into the research problem. Further research, however, is required to verify the extent to which the research findings can be generalised to the larger population and in other service contexts. Furthermore, the current model focuses only on the consumer advocacy and helping dimensions of customer citizenship behaviour. Future studies could expand the model by including other dimensions of customer citizenship behaviour. A list of additional customer citizenship behaviours is provided in the literature review of this article. Other relationship quality factors could also be explored, such as the impact of trust on customer citizenship behaviour. Additionally, it is possible that the social desirability of the 
respondents may have influenced some of their responses concerning customer citizenship behaviour. It is therefore recommended that the same study be repeated on a broader scale, involving a more representative sample and with additional measurement items to verify the findings of this study. Qualitative research could also be conducted to obtain more insight into the role of customer citizenship behaviour and its relevant antecedents within an online environment.

\section{Acknowledgements Competing interests}

The authors declare that they have no financial or personal relationship(s) that may have inappropriately influenced them in writing this article.

\section{Authors' contributions}

Both authors were responsible for the conceptualisation of this study. E.v.T. contributed to the introduction, literature review, methodology and implications, while L.T.d.B. did statistical analysis.

\section{References}

Allen, N.J. \& Meyer, J.P., 1990, 'The measurement and antecedents of affective, continuance, and normative commitment to the organization', Journal of Occupationa Psychology 63, 1-18. https://doi.org/10.1111/j.2044-8325.1990.tb00506.x

Anaza, N.A., 2014, 'Personality antecedents of customer citizenship behaviors in online shopping situations', Psychology \& Marketing 31(4), 251-263. https://doi. org/10.1002/mar.20692

Anaza, N.A. \& Zhao, J., 2013, 'Encounter-based antecedents of e-customer citizenship behaviors', Journal of Services Marketing 27(2), 130-140. https://doi.org/ 10.1108/08876041311309252

Anderson, E. \& Weitz, B., 1992, 'The use of pledges to build and sustain commitment in distribution channels', Journal of Marketing Research 29(1), 18-34. https://doi. org $/ 10.2307 / 3172490$

Balaji, M.S., 2014, 'Managing customer citizenship behavior: A relationship perspective', Journal of Strategic Marketing 22(3), 222-239. https://doi.org/10.1 080/0965254X.2013.876076

Bendapudi, N., Singh, S.N. \& Bendapudi, V., 1996, 'Enhancing helping behaviour: An integrative framework for promotion planning', Journal of Marketing 60(3), 33-49. https://doi.org/10.2307/1251840

Berry, L.L., 1983, 'Relationship marketing', in L. Berry, G.L. Shostack \& G.D. Upah (eds.), Emerging perspectives on services marketing, pp. 25-28, American Marketing Association, Chicago, IL.

Bitner, M.J., 1990, 'Evaluating service encounters: The effect of physical surrounding and employee responses', Journal of Marketing 54, 69-82. https://doi. org/10.2307/1251871

Blau, P.M., 1964, Exchange and power in social life, Wiley, New York.

Bolton, R.N. \& Drew, J.H., 1991, 'A multi-stage model of customers' assessment of service quality and value', Journal of Consumer Research 17, 375-385. https://doi. org/10.1086/208564

Bove, L., Robertson, N. \& Pervan, S., 2003, 'Customer citizenship behaviours: Towards the development of a typology', in R. Kennedy (ed.), ANZMAC 2003: A celebration of Ehrenberg and Bass: Marketing discoveries, knowledge and contribution: Conference proceedings, University of South Australia, Adelaide, 1-3 December, pp. 331-338.

Bove, L.L., Pervan, S.J., Beatty, S.E. \& Shiu, E., 2009, 'Service worker role in encouraging customer organizational citizenship behaviors', Journal of Business Research 62, 698-705. https://doi.org/10.1016/j.jbusres.2008.07.003

Brodie, R., 2017, 'Enhancing theory development in the domain of relationship marketing: How to avoid the danger of getting stuck in the middle', Journal of Services Marketing 31(1), 20-23. https://doi.org/10.1108/JSM-05-2016-0179

Brown, T.A., 2015, Confirmatory factor analysis for applied research, The Guilford Press, New York.

Byrne, B.M., 1998, Structural equation modeling with LISREL, PRELIS and SIMPLIS: Basic concepts, applications and programming, Lawrence Erlbaum Associates, Mahwah, NJ.

Caruana, A., 2002, 'Service loyalty: The effects of service quality and the mediating role of customer satisfaction', European Journal of Marketing 36(7/8), 811-828. https://doi.org/10.1108/03090560210430818
Chelminski, P. \& Coulter, R.A., 2011, 'An examination of consumer advocacy and complaining behavior in the context of service failure', Journal of Services Marketing 25(5), 361-370. https://doi.org/10.1108/08876041111149711

Chen, M.-J., Chen, C.-D. \& Farn, C.-K., 2010, 'Exploring determinants of citizenship behavior on virtual communities of consumption: The perspective of social exchange theory', International Journal of Electronic Business Management 8, 195-205.

Chiu, W., Kwag, M.-S. \& Bae, J.-S., 2015, 'Customers as partial employees: The influences of satisfaction and commitment on customer citizenship behavior in fitness centers', Journal of Physical Education and Sport 15(4), 627-633.

Cohen, J., 1992, Statistical power analysis for the behavioral sciences, Rev. edn., Academic Press, Orlando, FL.

Cronin, J.J. \& Taylor, S.A., 1994, 'SERVPERF versus SERVQUAL: Reconciling performance-based and perception-minus-expectations measurement of service quality', Journal of Marketing 58, 125-131. https://doi.org/10.2307/1252256

Curth, S., Uhrich, S. \& Benkenstein, M., 2014, 'How commitment to fellow customers affects the customer-firm relationship and customer citizenship behavior', Journal of Services Marketing 28(2), 147-158. https://doi.org/10.1108/JSM-082012-0145

Czepiel, J.A., Rosenberg, L.J. \& Akerele, A., 1974, 'Perspectives on consumer satisfaction', in R.C. Curhan (ed.), Marketing's contribution to the firm and society, AMA Educators' Proceedings, pp. 119-123, American Marketing Association, Chicago, IL.

Dagger, T.S. \& O'Brien, T.K., 2010, 'Does experience matter? Differences in relationship benefits, satisfaction, trust, commitment and loyalty for novice and experienced service users', European Journal of Marketing 44(9/10), 1528-1552. https://doi. org/10.1108/03090561011062952

DeVellis, R.F., 2012, Scale development: Theory and applications, 3rd edn., Sage, Thousand Oaks, CA.

Dimitriades, Z.S., 2006, 'Customer satisfaction, loyalty and commitment in service organizations: Some evidence from Greece', Management Research News 29(12) 782-800. https://doi.org/10.1108/01409170610717817

Emerson, R.M., 1976, 'Social exchange theory', Annual Review of Sociology 2, 335362. https://doi.org/10.1146/annurev.so.02.080176.002003

Fornell, C. \& Larcker, D.F., 1981, 'Structural equation models with unobservable variables and measurement error: Algebra and statistics', Journal of Marketing Research 18(3), 382-388. https://doi.org/10.2307/3150980

Fowler, J.G. 2014, 'Customer citizenship behavior: An expanded theoretical understanding', International Journal of Business and Social Science 4(5), 1-8, viewed 19 October 2017, from http://ijbssnet.com/journals/Vol_4_No_5 May_2013/1.pdf

Fullerton, G., 2003, 'When does commitment lead to loyalty?', Journal of Service Research 5(4), 333-344. https://doi.org/10.1177/1094670503005004005

Garbarino, E. \& Johnson, M.S., 1999, 'The different roles of satisfaction, trust, and commitment in customer relationships', Journal of Marketing 63(2), 70-87. https://doi.org/10.2307/1251946

Gilde, C., Pace, S., Pervan, S. \& Strong, C., 2011, 'Examining the boundary conditions of customer citizenship behaviour: A focus on consumption ritual', Journal of Strategic Marketing 19(7), 619-631. https://doi.org/10.1080/0965254X.2011. 603053

Grönroos, C., 1983, Strategic management and marketing in the service sector, Marketing Science Institute, Boston, MA.

Groth, M., 2005, 'Customers as good soldiers: Examining citizenship behaviors in internet service deliveries', Journal of Management 31(1), 7-27. https://doi. org/10.1177/0149206304271375

Gruca, T.S. \& Rego, L.L., 2005, 'Customer satisfaction, cash flow, and shareholder value', Journal of Marketing 69(3), 115-130. https://doi.org/10.1509/jmkg. 69.3.115.66364

Gruen, T.W. 1995, 'The outcome set of relationship marketing in consumer markets', International Business Review 4(4), 447-469. https://doi.org/10.1016/0969 5931(95)00026-7

Gummerus, J., Von Koskull, C. \& Kowalkowski, C., 2017, 'Guest editorial: Relationship marketing - Past, present and future', Journal of Services Marketing 31(1), 1-5. https://doi.org/10.1108/JSM-12-2016-0424

Gummesson, E., 2017, 'From relationship marketing to total relationship marketing and beyond', Journal of Services Marketing 31(1), 16-19. https://doi.org/10.1108/ JSM-11-2016-0398

Hair, J.F., Anderson, R.E., Babin, B.J. \& Black, W.C., 2010, Multivariate data analysis: A global perspective, vol. 7, Pearson, Upper Saddle River, NJ.

Hajli, M.N., 2014, 'The role of social support on relationship quality and socia commerce', Technological Forecasting and Social Change 87, 17-27. https://doi. org/10.1016/j.techfore.2014.05.012

Hamadi, C., 2011, 'The moderating role of need for personal interaction in the relationship between e-quality, e-satisfaction and commitment: "Case of Moroccan e-banking users"', IBIMA Business Review Vol. 2011 (2011), Article ID Moroccan e-banking users"', IBIMA Business Review Vol.
625728,11 pages. https://doi.org/10.5171/2011.625728

Hennig-Thurau, T., 2004, 'Customer orientation of service employees: Its impact on customer satisfaction, commitment, and retention', International Journal of Service Industry Management 15(5), 460-478. https://doi.org/10.1108/09564 230410564939

Hennig-Thurau, T., Gwinner, K.P. \& Gremler, D.D., 2002, 'Understanding relationship marketing outcomes: An integration of relational benefits and relationship quality', Journal of Service Research 4(3), 230-247. https://doi.org/ 10.1177/1094670502004003006 
Hennig-Thurau, T. \& Klee, A., 1997, 'The impact of customer satisfaction and relationship quality on customer retention - A critical reassessment and model development', Psychology \& Marketing 14, 737-765. https://doi.org/10.1002/ development', Psychology \& Marketing 14, 737-765. https://d
(SICI)1520-6793(199712)14:8\%3C737::AID-MAR2\%3E3.0.CO;2-F

Hibbert, S.A., Hogg, G. \& Quinn, T., 2002, 'Consumer response to social entrepreneurship: The case of the big issue in Scotland', International Journal of Nonprofit and Voluntary Sector Marketing 7(3), 288-301. https://doi.org/10.1002/ nomprofit 186

Homans, G.C., 1958, 'Social behavior as exchange', American Journal of Sociology 63 , 597-606. https://doi.org/10.1086/222355

Howard, A.J. \& Sheth, J.N., 1969, The theory of buyer behavior, Wiley, New York.

Iacobucci, D., Ostrom, A. \& Grayson, K., 1995, 'Distinguishing service quality and customer satisfaction: The voice of the consumer', Journal of Consume Psychology 4(3), 277-303. https://doi.org/10.1207/s15327663jcp0403_04

Izogo, E.E., 2017, 'Customer loyalty in telecom service sector: The role of service quality and customer commitment', The TQM Journal 29(1), 19-36. https://doi. org/10.1108/TQM-10-2014-0089

Johnson, M.S., Sivadas, E. \& Garbarino, E., 2008, 'Customer satisfaction, perceived risk and affective commitment: An investigation of directions of influence', Journal of Services Marketing 22(5), 353-362. https://doi.org/10.1108/08876040810889120

Johnson, Z., Massiah, C. \& Allan, J., 2013, 'Community identification increases consumer-to-consumer helping, but not always', Journal of Consumer Marketing 30(2), 121-129. https://doi.org/10.1108/07363761311304933

Jones, M.A., Reynolds, K.E., Arnold, M.J., Gabler, C.B., Gillison, S.T. \& Landers, V.M., 2015, 'Exploring consumers' attitude towards relationship marketing', Journal of Services Marketing 29(3), 188-199. https://doi.org/10.1108/JSM-04-2014-0134

Jones, T., Fox, G.L., Taylor, S.F. \& Fabrigar, L.R., 2010, 'Service customer commitment and response', Journal of Services Marketing 24(1), 16-28. https://doi. org/10.1108/08876041011017862

Jung, J.H. \& Yoo, J.J., 2016, 'Customer-to-customer interactions on custome citizenship behavior', Service Business 11, 117-139. https://doi.org/10.1007/ s11628-016-0304-7

Kundu, S. \& Datta, S.K., 2015, 'Impact of trust on the relationship of e-service quality and customer satisfaction', EuroMed Journal of Business 10(1), 21-46. https://doi. org/10.1108/EMJB-10-2013-0053

Liu, S.Q. \& Mattila, A.S., 2015, “I want to help" versus “I am just mad”: How affective commitment influences customer feedback decisions', Cornell Hospitality Quarterly 56(2), 213-222. https://doi.org/10.1177/1938965515570939

Mitchell, M.S., Cropanzano, R.S. \& Quisenberry, D.M., 2012, 'Social exchange theory, exchange resources, and interpersonal relationships: A modest resolution of theoretical difficulties', in K. Törnblom \& A. Kazemi (eds.), Handbook of socia resource theory, pp. 99-118, Springer, New York.

Morgan, R.M. \& Hunt, S.D., 1994, 'The commitment-trust theory of relationship marketing', Journal of Marketing 58, 20-38. https://doi.org/10.2307/1252308

Muthén, L.K. \& Muthén, B.O., 2016, Mplus user's guide, 7th ed., Muthén \& Muthén, Los Angeles, CA.

Narteh, B., 2015, 'Perceived service quality and satisfaction of self-service technology', International Journal of Quality \& Reliability Management 32(4), 361-380. https://doi.org/10.1108/IJQRM-08-2012-0113

News24, 2015, South Africans are wary of Internet banking, viewed 27 February 2017 from https://mybroadband.co.za/news/banking/130244-south-africans-are-wearyof-internet-banking.html

Oliver, R.L., 1981, 'What is customer satisfaction?', The Wharton Magazine 5(3), 36-41.

Oliver, R.L., 1989, 'Processing of the satisfaction response in consumption: A suggested framework and research propositions', Journal of Consumer Satisfaction, Dissatisfaction and Complaining Behavior 2, 1-16.

Oliver, R.L., 1993, 'A conceptual model of service quality and service satisfaction: Compatible goals and different concepts', in T.A. Swart, D.E. Bowen \& S.W. Brown (eds.), Advances in Service Marketing and Management, vol. 3, pp. 65-86, JA Press, Greenwich, CT.

Paillé, P., Grima, F. \& Dufour, M.-È., 2015, 'Contribution to social exchange in public organizations: Examining how support, trust, satisfaction, commitment and work outcomes are related', The International Journal of Human Resource Management 26(4), 520-546. https://doi.org/10.1080/09585192.2012.654809

Parasuraman, A., Zeithaml, V.A. \& Berry, L.L., 1988, 'SERVQUAL: A multiple-item scale for measuring consumer perceptions of service quality', Journal of Retailing 64, 12-40.

Patterson, P.G., Razzaque, M.A. \& Terry, C.S.L., 2003, 'Customer citizenship behaviour in service organisations: A social exchange model', in R. Kennedy (ed.), ANZMAC 2003: A celebration of Ehrenberg and Bass: Marketing discoveries, knowledge and contribution: Conference proceedings, University of South Australia, Adelaide, December 1-3, pp. 2079-2089.

Payne, A. \& Frow, P., 2017, 'Relationship marketing: Looking backwards towards the future', Journal of Services Marketing 31(1), 11-15. https://doi.org/10.1108/JSM$11-2016-0380$

Petzer, D.J., De Meyer-Heydenrych, C.F. \& Svensson, G., 2017, 'Perceived justice, service satisfaction and behavior intentions following service recovery efforts in a South African retail banking context', International Journal of Bank Marketing 35(2), 241-253. https://doi.org/10.1108/IJBM-04-2016-004

Pizam, A. \& Ellis, T., 1999, 'Customer satisfaction and its measurement in hospitality enterprises', International Journal of Contemporary Hospitality Managemen 11(7), 326-339. https://doi.org/10.1108/09596119910293231

Ponnusamy, G. \& Ho, J.S.Y., 2015, 'Customers as volunteers? E-customer citizenship behavior and its antecedents', Information Management and Business Review $7(3), 50$.

Preacher, K.J. \& Hayes, A.F., 2008, 'Asymptotic and resampling strategies for assessing and comparing indirect effects in multiple mediator models', Behavior Research Methods 40, 879-891. https://doi.org/10.3758/BRM.40.3.879

Price, L.L., Feick, L.F. \& Guskey, A., 1995, 'Everyday market helping behavior', Journal of Public Policy \& Marketing 14(2), 255-266.

PricewaterhouseCoopers (PwC), 2016, Getting the balance right: Major banks analysis South Africa, viewed 19 March 2017, from http://www.pwc.co.za/en/assets/pdf/ major-banks-analysis-september-2016.pdf

Sheth, J., 2017, 'Revitalizing relationship marketing', Journal of Services Marketing 31(1), 6-10. https://doi.org/10.1108/JSM-11-2016-0397

Shukla, P., Banerjee, M. \& Singh, J., 2016, 'Customer commitment to luxury brands: Antecedents and consequences', Journal of Business Research 69(1), 323-331. https://doi.org/10.1016/j.jbusres.2015.08.004

Smith, B., 1998, 'Buyer-seller relationships: Bonds, relationship management, and sextype', Canadian Journal of Administrative Sciences/Revue Canadienne des Sciences de l'Administration 15(1), 76-92. https://doi.org/10.1111/j.1936-4490.1998. tb00153.x

South Africa, 2013, 'The Protection of Personal Information Act, 2013', Notice 912 2013, Government Gazette 581(37067), 26 November.

Spreng, R.A. \& Mackoy, R.D., 1996, 'An empirical examination of a model of perceived service quality and satisfaction', Journal of Retailing 72(2), 201-214. https://doi. org/10.1016/S0022-4359(96)90014-7

Tabachnick, B.G. \& Fidell, L.S., 2001, Using multivariate statistics, 4th ed., Harper \& Row, New York.

Tung, V.W.S., Chen, P.-J. \& Schuckert, M., 2017, 'Managing customer citizenship behaviour: The moderating roles of employee responsiveness and organizational reassurance', Tourism Management 59, 23-35. https://doi.org/10.1016/j. tourman.2016.07.010

Van de Schoot, R., Lugtig, P. \& Hox, J., 2012, 'A checklist for testing measurement invariance', European Journal of Developmental Psychology 9(4), 486-492. https://doi.org/10.1080/17405629.2012.686740

Van Tonder, E., Petzer, D.J. \& Van Zyl, K., 2017, 'A mediated model of relationship quality factors affecting behavioural intention at a luxury motor vehicle dealership', European Business Review 29(1), 43-60. https://doi.org/10.1108/ EBR-08-2016-0113

Vesel, P. \& Zabkar, V., 2010, 'Relationship quality evaluation in retailers' relationships with consumers', European Journal of Marketing 44(9/10), 1334-1365. https:// doi.org/10.1108/03090561011062871

Wu, S.-H., Huang, S.C.-T., Tsai, C.-Y.D. \& Lin, P.-Y., 2017, 'Customer citizenship behavior in social networking sites: The role of relationship quality, identification, and service attributes', Internet Research 27(2), 428-448. https://doi.org/10.1108/ service attributes',
IntR-12-2015-0331

Yi, Y. \& Gong, T., 2008, 'If employees "go the extra mile," do customers reciprocate with similar behavior?', Psychology \& Marketing 25(10), 961-986. https://doi. org/10.1002/mar.20248

Yi, Y. \& Gong, T., 2013, 'Customer value co-creation behavior: Scale development and validation', Journal of Business Research 66(9), 1279-1284. https://doi. org/10.1016/j.jbusres.2012.02.026

Yuksel, A. \& Yuksel, F., 2001, 'Measurement and management issues in customer satisfaction research: Review, critique and research agenda: Part one', Journal of Travel and Tourism Marketing 10(4), 47-80. https://doi.org/10.1300/ J073v10n04_03

Zhao, X., Lynch, J.G. \& Chen, Q., 2010, 'Reconsidering Baron and Kenny: Myths and truths about mediation analysis', Journal of Consumer Research 37, 197-206. https://doi.org/10.1086/651257 